\title{
PERBEDAAN PENGGUNAAN LABORATORIUM REAL DAN LABORATORIUM VIRTUAL PADA KETERAMPILAN PROSES DAN HASIL BELAJAR SISWA MATERI TITRASI ASAM BASA
}

\author{
Nanik Sulistiowati ${ }^{1}$ \\ Leny Yuanita ${ }^{2}$ \\ Wasis $^{2}$ \\ ${ }^{1}$ SMA Ulul Albab Taman Sidoarjo \\ ${ }^{2}$ Pascasarjana Prodi Pendidikan Sains Universitas Negeri Surabaya \\ e-mail:naniks_86@yahoo.co.id
}

\begin{abstract}
The research was an experimental study to identify differences on process skills and student's achievement by using real and virtual laboratories in acid base titration. The subject was students of $11^{\text {st }}$ science class at Wachid Hasyim 2 Taman Sidoarjo High School. The research used 4 classes with real laboratory learning class as a control class while 3 classes given by the virtual laboratory as an experimental classes. Design of research was Control Group pre-test-post-test design. The result was a feasibility lesson plans on using real laboratory showed similar results with learning using virtual laboratory were categorized very well, student activity during the learning process using real and virtual laboratory showed the same result were an increase in inquiry activities. The average value of the process skills of students used real laboratory on control class is 79,12 and virtual laboratory on experiment class 1, 2, and 3 were 80,18; 79,88; and 81,16 respectively. The average value the results of student's achievement used real laboratory on control class is 78,25 and virtual laboratory on experiment class 1, 2, and 3 were 79,48; 79,63; and 80,26 respectively. Process skills showed correlation with student's achievement in use real and virtual laboratories. The conclusion was there are no differences in the skills process and student's achievement by using real and virtual laboratories in acid base titration therefore virtual laboratory could be used as simulation media in schools with computing facilities before students learn using real laboratory. The virtual laboratory were not a competitor and didn't function to replace the real laboratory.
\end{abstract}

Keywords: process skills, real laboratory, student's achievement, virtual laboratory.

\begin{abstract}
Abstrak: Penelitian ini merupakan penelitian eksperimental yang bertujuan untuk mengetahui perbedaan keterampilan proses dan hasil belajar siswa dengan menggunakan laboratorium real dan laboratorium virtual materi titrasi asam basa. Subyek penelitian adalah siswa kelas XI IPA di SMA Wachid Hasyim 2 Taman Sidoarjo. Uji coba penelitian menggunakan 4 kelas dengan pembagian 1 kelas diberikan pembelajaran dengan laboratorium real sebagai kelas kontrol sedangkan 3 kelas diberikan pembelajaran dengan laboratorium virtual sebagai kelas eksperimen. Penelitian ini menggunakan rancangan penelitian Control Group pre-test-post-test Design. Hasil dari penelitian ini adalah keterlaksanaan RPP pada pembelajaran menggunakan laboratorium real menunjukkan hasil yang sama dengan pembelajaran menggunakan laboratorium virtual yaitu berkategori sangat baik, aktivitas siswa selama pros es pembelajaran menggunakan laboratorium real dan laboratorium virtual menunjukkan hasil yang sama yaitu mengalami peningkatan dalam kegiatan inkuiri. Nilai rata-rata keterampilan proses siswa yang menggunakan laboratorium real pada kelas kontrol sebesar 79,12 dan menggunakan laboratorium virtual pada kelas eksperimen 1, 2, dan 3 berturut-turut sebesar 80,18; 79,88; dan 81,16. Nilai rata-rata hasil belajar siswa yang menggunakan laboratorium real pada kontrol sebesar 78,25 dan menggunakan laboratorium virtual pada kelas eksperimen 1, 2, dan 3 berturut-turut sebesar 79,48; 79,63; dan 80,26. Keterampilan proses menunjukkan adanya korelasi dengan hasil belajar produk pada pembelajaran yang menggunakan laboratorium real dan laboratorium virtual. Simpulan dari penelitian ini adalah tidak ada perbedaan pada keterampilan proses dan hasil belajar siswa dengan menggunakan laboratorium real dan laboratorium virtual materi titrasi asam basa sehingga laboratorium virtual dapat digunakan sebagai media simulasi pada sekolah yang memiliki fasilitas komputasi sebelum siswa belajar menggunakan laboratorium real. Laboratorium virtual bukanlah kompetitor dan tidak difungsikan untuk menggantikan laboratorium real.
\end{abstract}

Kata Kunci: hasil belajar siswa, keterampilan proses, laboratorium real, laboratorium virtual.

\section{PENDAHULUAN}

Kimia merupakan cabang dari ilmu pengetahuan alam yang mencakup konsep dan eksperimen untuk mencari jawaban atas pertanyaan apa, mengapa dan bagaimana gejala-gejala alam yang berkaitan dengan komposisi, struktur dan sifat, perubahan, dinamika dan energetika zat. Ilmu kimia tidak pernah terpisahkan dari kegiatan laboratorium karena sesuai dengan hakekatnya di sekolah IPA seharusnya dipelajari oleh siswa dengan mengadakan kontak langsung dengan obyek yang diselidiki 
itu menggunakan indera sendiri atau dengan indra pertolongan alat bantu belajar. Siswa melakukan pengamatan (observation) dan atau percobaan (experiment) terhadap obyek yang dipelajari melalui kegiatan laboratorium.

Kegiatan laboratorium dengan metode eksperimen memiliki peranan yang sangat penting dalam pembelajaran kimia. Metode eksperimen merupakan salah satu cara belajar yang efektif dengan menyertakan peran aktif siswa di dalamnya yang berguna dalam meningkatkan daya ingat dalam pembelajaran. Hasil penelitian Georgiou, et al (2007) menunjukkan bahwa manusia hanya mengingat $10 \%$ dari apa yang siswa baca, 20\% dari apa yang siswa dengar, tapi mempertahankan hingga $90 \%$ dari apa yang siswa pelajari melalui partisipasi aktif. Salah satu partisipasi aktif dalam pembelajaran kimia adalah melaksanakan kegiatan laboratorium.

Hasil observasi dan wawancara dengan beberapa guru kimia di lima SMA di Surabaya dan Sidoarjo menunjukkan bahwa (1) kegiatan laboratorium jarang dilakukan dalam pembelajaran kimia di sekolah karena adanya berbagai kendala, seperti alat dan bahan yang terbatas dan biaya praktikum yang mahal, (2) aktivitas siswa pada kegiatan laboratorium selain melakukan eksperimen didominasi oleh mencatat dan mendengarkan, (3). Dari sejumlah materi yang menggunakan kegiatan laboratorium, Titrasi Asam Basa merupakan pokok bahasan dalam kegiatan laboratorium yang memerlukan banyak pengadaan bahan dan memungkinkan terjadi resiko kecelakaan kerja misalnya pecahnya buret. Titrasi asam basa merupakan kegiatan laboratorium "mahal" yang dituntut ketelitian yang tinggi, sehingga diperlukan persiapan dan latihan khusus sebelum siswa menghadapi secara langsung dalam kegiatan laboratorium yang sesungguhnya (real). Kendala teknis pada penggunaan laboratorium real dapat diatasi dengan melakukan simulasi menggunakan laboratorium virtual (Dineva, 2011). Laboratorium virtual dapat menjadi bagian dari persiapan dan latihan khusus pada kegiatan laboratorium real materi Titrasi Asam Basa sehingga dapat dilakukan berulangulang untuk melatihkan ketelitian dalam pengamatan tanpa menimbulkan masalah biaya dan keselamatan kerja. Penggunaan laboratorium virtual dapat digunakan sebagai pembelajaran simulasi sebelum siswa belajar materi titrasi asam basa secara langsung dalam laboratorium real.

Laboratorium virtual merupakan bentuk laboratorium dengan kegiatan pengamatan dan percobaan yang dilakukan menggunakan software komputer dengan tampilan seperti peralatan laboratorium real. Laboratorium virtual memiliki banyak keuntungan antara lain (1) penggunaaan laboratorium virtual dapat menghemat biaya pengadaan percobaan, (2) penggunaan laboratorium virtual dapat memperbaiki pemahaman siswa artinya melalui laboratorium virtual siswa dapat memanipulasi variabel dan mengumpulkan data dengan cepat dan berulang sehingga semakin sering berlatih siswa akan semakin paham dengan materi ajar, dan (3) memberikan respon positif serta menarik minat dan ketertarikan siswa terhadap kegiatan pembelajaran. Laboratorium virtual dapat dilakukan di sekolah manapun yang memiliki laboratorium komputer salah satunya SMA Wachid Hasyim 2 Taman Sidoarjo. Pertimbangan memilih tempat untuk menerapkan laboratorium virtual ini didasarkan pada kenyataan bahwa SMA Wachid Hasyim 2 Taman Sidoarjo yang memiliki laboratorium kimia dan laboratorium komputer yang bisa dijadikan sebagai tempat kegiatan praktikum dengan laboratorium virtual. Bailenson (2008) menyatakan bahwa pembelajaran dengan menggunakan media komputer dapat mewaliki bentuk nyata dari suatu benda untuk dipelajari sehingga media komputer dapat meningkat proses pembelajaran. Proses pembelajaran yang meningkat salah satunya disebabkan oleh meningkatnya keterampilan proses (Semiawan, 1992). Pengalaman langsung dari segala kegiatan laboratorium dapat lebih menghayati proses atau kegiatan dalam laboratorium yang sedang dilakukan sehingga menghasilkan suatu keterampilan kinerja. Kegiatan laboratorium penting bagi siswa guna mengembangkan keterampilan proses dengan aspek-aspeknya karena keterampilan proses mempengaruhi pemahaman konsep (Soebagyo, 2009).

Berdasarkan latar belakang dan harapan dalam upaya pembelajaran kimia yang inovatif terutama pada pengadaan percobaan di laboratorium yang didukung dengan hasil penelitian yang relevan, maka peneliti mengambil judul "Perbedaan Penggunaan Laboratorium Real dan Laboratorium Virtual pada Keterampilan Proses dan Hasil Belajar Siswa Materi Titrasi Asam Basa”. Rumusan masalah dalam penelitian ini adalah "Bagaimanakah perbedaan keterampilan proses dan hasil belajar siswa dengan menggunakan laboratorium real dan laboratorium virtual materi titrasi asam basa?". Rincian rumusan masalah tersebut dapat dijabarkan sebagai berikut :

1. Bagaimanakah keterlaksanaan pembelajaran dengan menggunakan laboratorium real dan laboratorium virtual pada materi Titrasi Asam Basa?

2. Bagaimankah aktivitas siswa selama pembelajaran dengan menggunakan laboratorium real dan laboratorium virtual pada materi Titrasi Asam Basa?

3. Apakah ada perbedaan keterampilan proses setelah mengikuti pembelajaran kimia dengan menggunakan laboratorium real dan laboratorium virtual pada materi Titrasi Asam Basa? 
4. Apakah ada perbedaan hasil belajar produk setelah mengikuti pembelajaran kimia dengan menggunakan laboratorium real dan laboratorium virtual pada materi Titrasi Asam Basa?

5. Bagaimanakan respon siswa setelah mengikuti pembelajaran kimia materi titrasi asam basa dengan menggunakan laboratorium real dan laboratorium virtual pada materi Titrasi Asam Basa?

\section{METODE PENELITIAN}

Penelitian ini merupakan penelitian eksperimental (True Eksprimental) karena terdapat randomisasi, kontrol, dan replikasi. Penelitian ini diawali mengembangkan perangkat pembelajaran kimia. Perangkat pembelajaran yang akan dikembangkan adalah Lembar Kerja Siswa (LKS), Rencana Pelaksanaan Pembelajaran (RPP), Lembar Penilaian (LP), InstrumenbLembar Pengamatan (Keterlaksanaan RPP, aktivitas siswa, kendala Lapangan), dan Instrumen Angket Respon Siswa.

Sasaran penelitian adalah siswa kelas XI IPA tahun ajaran 2012/2013. Penelitian ini menggunakan 4 kelas yang diambil secara random dengan pembagian kelas diberikan pembelajaran dengan menggunakan laboratorium real sebagai kelas control dan kelas diberikan pembelajaran dengan menggunakan laboratorium virtual sebagai kelas eksperimen dengan replikasi tiga kali. Penelitian ini menggunakan rancangan penelitian Control Group pretest-post-test Design dengan pola sebagai berikut:

Tabel 1. Rancangan Penelitian

\begin{tabular}{|c|c|c|c|}
\hline Kelompok & Pretest & Perlakuan & Posttest \\
\hline Kontrol & $\mathrm{O}_{1}$ & $\mathrm{X}_{1}$ & $\mathrm{O}_{2}$ \\
\hline Eksperimen & $\mathrm{O}_{1}$ & $\mathrm{X}_{2}$ & $\mathrm{O}_{2}$ \\
\hline
\end{tabular}

(Arikunto, 2002)

Keterangan :

$\mathrm{O}_{1}=$ Pretest

$\mathrm{O}_{2}=$ Posttest

$\mathrm{X} 1=$ Pembelajaran inkuiri dengan menggunakan laboratorium real

$\mathrm{X} 2$ = Pembelajaran inkuiri dengan menggunakan laboratorium virtual

Teknik observasi digunakan untuk memperoleh data penelitian yang diamati selama proses pembelajaran. Observasi dilakukan oleh dua orang pengamat untuk mengamati keterlaksanaan RPP, dan dua pengamat lainnya untuk mengamati aktivitas siswa.

Teknik analisis data yang digunakan adalah analisis deskriptif kuantitatif meliputi analisis keterlaksanaan RPP, analisis hasil pengamatan aktifitas siswa, perbedaan pencapaian keterampilan proses dan hasil belajar siswa menggunakan laboratorium real dan laboratorium virtual.

Pengamatan keterlaksanaan RPP dilakukan oleh dua orang pengamat dengan mengisi lembar observasi. Penilaian keterlaksanaan RPP dimulai dari pendahuluan, kegiatan inti, penutup dan pengelolaan waktu. Hasil penilaian kedua pengamat untuk setiap aspek yang diamati dengan kriteria penilaian sebagai berikut:

Tabel 2. Kriteria Pengkategorian Penilaian Perangkat Pembelajaran

\begin{tabular}{|c|c|}
\hline Interval Skor & Kategori Penilaian \\
\hline $3,5 \leq \mathrm{P}<4,0$ & Sangat Baik / valid \\
\hline $2,5 \leq \mathrm{P}<3,5$ & Baik / valid \\
\hline $1,5 \leq \mathrm{P}<2,5$ & Kurang Baik \\
\hline $1,0 \leq \mathrm{P}<1,5$ & Tidak Baik \\
\hline
\end{tabular}

Diadopsi dari Ratumanan (2006)

Hasil pengamatan perbedaan pencapaian keterampilan proses dan hasil belajar siswa dianalisis menggunakan statistik inferensial parametrik Uji Anava One Way dengan menggunakan SPSS 16 untuk mengetahui ada atau tidak ada perbedaan perbedaan pencapaian keterampilan proses dan hasil belajar siswa pada satu kelas yang menggunakan laboratorium real sebagai kelas kontrol dan tiga kelas yang menggunakan laboratorium virtual sebagai kelaas eksperimen.

\section{HASIL DAN PEMBAHASAN}

Hasil penelitian disusun berdasarkan data yang diperoleh dari uji coba yang telah dilaksanakan di SMA Wachid Hasyim 2 Taman Sidoarjo dengan subyek penelitian siswa kelas XI IPA 1 XI IPA 2, XI IPA 3, dan XI IPA 4. Hasil penelitian diuraikan sebagai berikut:

\section{Hasil Validasi Perangkat}

Hasil validasi berupa telaah, penilaian, dan saran dari validator mengenai RPP, LKS, dan LP. Hasil analisis penilaian perangkat tersebut secara singkat disajikan pada Tabel 3.

Tabel 3. Hasil Penilaian RPP, LKS dan LP

\begin{tabular}{|c|c|c|c|c|}
\hline No & $\begin{array}{c}\text { Jenis } \\
\text { Perangkat }\end{array}$ & $\begin{array}{c}\text { Aspek } \\
\text { Penilaian }\end{array}$ & $\begin{array}{c}\text { Nilai } \\
\text { Rata-Rata }\end{array}$ & Kategori \\
\hline \multirow[t]{6}{*}{1} & \multirow[t]{6}{*}{ RPP } & $\begin{array}{c}\text { Tujuan } \\
\text { Pembelajaran }\end{array}$ & 3.56 & Sangat Baik \\
\hline & & $\begin{array}{c}\text { Kegiatan } \\
\text { Pembelajaran }\end{array}$ & 3.36 & Baik \\
\hline & & Waktu & 3.60 & Sangat Baik \\
\hline & & $\begin{array}{c}\text { Perangkat } \\
\text { Pembelajaran }\end{array}$ & 3.60 & Sangat Baik \\
\hline & & Metode Sajian & 3.55 & Sangat Baik \\
\hline & & Bahasa & 3.07 & Baik \\
\hline \multirow[t]{4}{*}{2} & \multirow[t]{4}{*}{ LKS } & Petunjuk & 3.60 & Sangat Baik \\
\hline & & Kelayakan Isi & 3.01 & Baik \\
\hline & & Prosedur & 3.60 & Sangat Baik \\
\hline & & Pertanyaan & 3.60 & Sangat Baik \\
\hline \multirow[t]{2}{*}{3} & \multirow{2}{*}{$\begin{array}{c}\text { Lembar } \\
\text { Penilaian }\end{array}$} & Isi & 3.70 & Sangat Baik \\
\hline & & $\begin{array}{c}\text { Bahasa dan } \\
\text { penulisan soal }\end{array}$ & 3.80 & Sangat Baik \\
\hline
\end{tabular}


Hasil penilaian RPP meliputi aspek tujuan pembelajaran, kegiatan pembelajaran, waktu, perangkat pembelajaran, metode sajian dan bahasa mendapatkan nilai rata-rata 3,46 dalam kategori layak sebagai perangkat pembelajaran. Hasil penilaian LKS yang terdiri dari aspek petunjuk, kelayakan isi, prosedur dan pertanyaan mendapatkan nilai rata-rata 3,45. Hal ini menunjukkan bahwa LKS yang dikembangkan layak sebagai perangkat pembelajaran. Hasil penilaian LP yang terdiri dari aspek isi, bahasa dan penulisan soal mendapatkan nilai rata-rata 3,75. Hal ini menunjukkan bahwa LP yang dikembangkan layak sebagai perangkat pembelajaran.

Hasil penilaian RPP, LKS, dan LP oleh validator menunjukkan hasil yang valid. RPP yang dibuat sesuai kurikulum KTSP 2006 dan sintaks pembelajaran inkuiri dan melalui proses revisi untuk mendapatkan RPP yang layak. Menurut Ratumanan (2006), hasil penilaian yang valid menunjukkan bahwa perangkat pembelajaran yang dikembangkan layak dijadikan panduan guru dalam mengelolah pembelajaran untuk melatihkan keterampilan proses kepada siswa SMA. Hasil penilaian menunjukkan bahwa LP layak digunakan sebagai alat ukur pencapaian kompetensi dasar. Hasil analisis sensitivitas butir soal dalam LP menunjukkan bahwa sebanyak $100 \%$ dari 25 butir soal memiliki sensitivitas baik (peka) terhadap efek pembelajaran. Dengan demikian semua soal dapat digunakan menjadi instrumen penilaian karena suatu butir soal dikatakan peka terhadap efek-efek pembelajaran apabila sensitivitas butir soal $\geq 0,30$ (Aiken, 1997 dalam Suyidno, 2010).

\section{Keterlaksanaan RPP}

Berdasarkan hasil pengamatan dapat dikatakan bahwa secara umum keterlaksanaan RPP menggunakan laboratorium real sebagai kelas kontrol berada pada kategori sangat baik dengan penilaian rata-rata sebesar 3,67. Keterlaksanaan RPP menggunakan laboratorium real memiliki reliabilitas rata-rata sebesar $91 \%$. Berdasarkan data tersebut dapat dinyatakan bahwa instrumen yang digunakan reliabel. Keterlaksanaan RPP menggunakan laboratorium virtual sebagai kelas eksperimen 1, 2, dan 3 juga berada pada kategori sangat baik dengan penilaian rata-rata masing-masing sebesar 3,74; 3,75; dan 3,78. Keterlaksanaan RPP menggunakan laboratorium real memiliki reliabilitas berturut-turut sebesar 95\%, 94\%, dan 94\%. Berdasarkan data tersebut dapat dinyatakan bahwa instrumen yang digunakan reliabel.

Hasil pengamatan keterlaksanaan RPP baik pada pembelajaran menggunakan laboratorium real maupun laboratorium virtual diperoleh nilai yang terbesar pada saat kegiatan inti dengan fase membimbing merumuskan masalah, melakukan pengamatan, menyajikan hipotesis, menentukan identifikasi variabel, melakukan eksperimen, mengumpulkan data, dan menyimpulkan hasil eksperimen. Hal ini menunjukkan bahwa fase-fase dalam kegiatan inti sesuai dengan sintak pembelajaran inkuiri yaitu memperoleh dan mendapatkan informasi dengan melakukan penyelidikan. Inkuiri dapat dikatakan suatu metode yang mengacu pada suatu cara untuk mempertanyakan, mencari pengetahuan untuk informasi, atau mempelajari suatu gejala, hal ini diperkuat dengan pendapat Nur dan Wikandari (2000), strategi pembelajaran inkuiri merupakan bagian dari pembelajaran dengan penemuan, dalam pembelajaran penemuan, siswa didorong terlibat secara aktif untuk belajar dengan konsep-konsep dan prinsip-prinsip, dan guru mendorong siswa untuk memiliki pengalaman dengan melakukan eksperimen dan memungkinkan siswa menemukan prinsip-prinsip untuk diri mereka sendiri.

\section{Aktivitas Siswa}

Data hasil pengamatan aktivitas siswa pada ujicoba lapangan pada pembelajaran dengan laboratorium real dan laboratorium virtual didajikan pada Tabel .4.

Tabel 4. Hasil Pengamatan Aktivitas Siswa

\begin{tabular}{|c|c|c|c|c|c|c|c|c|c|}
\hline \multirow[t]{2}{*}{ No } & \multirow[t]{2}{*}{$\begin{array}{l}\text { Alktivitas } \\
\text { Siswa }\end{array}$} & \multicolumn{2}{|c|}{$\begin{array}{c}\text { Kelas } \\
\text { Kontrol }\end{array}$} & \multicolumn{2}{|c|}{$\begin{array}{c}\text { Kelas } \\
\text { Elssperi- } \\
\text { men I }\end{array}$} & \multicolumn{2}{|c|}{$\begin{array}{c}\text { Kelas } \\
\text { Eksperi- } \\
\text { men } 2\end{array}$} & \multicolumn{2}{|c|}{$\begin{array}{c}\text { Kelas } \\
\text { Elssperi- } \\
\text { men } 3\end{array}$} \\
\hline & & $\%$ & R & $\%$ & $\mathrm{R}$ & $\%$ & R & $\%$ & R \\
\hline 1 & $\begin{array}{l}\text { Membaca } \\
\text { (mencsri } \\
\text { informasi } \\
\text { dan } \\
\text { sebagainys) }\end{array}$ & 9 & & 7 & & 7 & & 7 & \\
\hline 2 & $\begin{array}{l}\text { Mendiskusi- } \\
\text { kan tugas }\end{array}$ & 9 & & 10 & & 9 & & 9 & \\
\hline 3 & Mencatat & 16 & & 17 & & 17 & & 17 & \\
\hline 4 & $\begin{array}{l}\text { Mendengar- } \\
\text { kan } \\
\text { penjelasan } \\
\text { guru }\end{array}$ & 12 & & 13 & & 13 & & 13 & \\
\hline 5 & $\begin{array}{l}\text { Melakukan } \\
\text { pengamatan, } \\
\text { merencana- } \\
\text { kan } \\
\text { elsaperimen, } \\
\text { melakukan } \\
\text { elsaperimen } \\
\text { atsu belkerja }\end{array}$ & 25 & $\begin{array}{l}93 \\
\%\end{array}$ & 25 & $\begin{array}{l}92 \\
\%\end{array}$ & 25 & $\begin{array}{l}94 \\
\%\end{array}$ & 26 & $\begin{array}{l}95 \\
\%\end{array}$ \\
\hline 6 & $\begin{array}{l}\text { Bertanys } \\
\text { kepada guru } \\
\text { atsu teman }\end{array}$ & 12 & & 12 & & 12 & & 12 & \\
\hline 7 & $\begin{array}{l}\text { Menyampai } \\
\text { kan } \\
\text { pendspat / } \\
\text { mengkomun } \\
\text { iksasikan } \\
\text { informasi } \\
\text { kepada kelas } \\
\text { dan guru }\end{array}$ & 13 & & 12 & & 12 & & 13 & \\
\hline 8 & $\begin{array}{l}\text { Perilaku } \\
\text { tidak: } \\
\text { relevan }\end{array}$ & 4 & & 4 & & 5 & & 5 & \\
\hline
\end{tabular}


Berdasarkan data Tabel 4 dapat dikatakan bahwa siswa yang menggunakan laboratorium real menunjukkan aktivitas membaca atau mencari informasi lebih tinggi pada pertemuan pertama, karena siswa dihadapkan pada materi baru sehingga membutuhkan waktu lebih lama untuk memahami materi tersebut, sementara pada pertemuan kedua dan ketiga siswa hanya mengingat informasi yang sudah dipelajari pada pertemuan sebelumnya. Aktivitas siswa dalam mendiskusikan tugas memperoleh persentase yang tidak jauh berbeda dari pertemuan pertama sampai pertemuan akhir karena tiap pertemuan siswa selalu dihadapkan materi yang membutuhkan diskusi antarkelompok. Aktivitas siswa dalam mendengarkan penjelasan guru tertinggi pada pertemuan pertama sebab siswa dominan mendengarkan penjelasan guru pada materi baru. Aktivitas siswa dalam menyampaikan pendapat diperoleh nilai tertinggi pada pertemuan ketiga. Hal ini menunjukkan bahwa pertemuan satu masih didominasi guru dalam menjelaskan informasi, sementara pada pertemuan kedua dan ketiga guru hanya mengingatkan prosedur yang digunakan serta membimbing diskusi. Selain itu aktivitas siswa dalam melakukan pengamatan, merencanakan eksperimen, melakukan eksperimen, atau bekerja frekuensinya lebih besar pada pertemuan kedua dan pertemuan ketiga terbesar dibandingkan aktivitas lain.

Siswa yang menggunakan laboratorium virtual baik pada kelas eksperimen 1, 2, dan 3 menunjukkan aktivitas membaca atau mencari informasi lebih tinggi pada pertemuan pertama, karena siswa dihadapkan pada materi baru sehingga membutuhkan waktu lebih lama untuk memahami materi tersebut, sementara pada pertemuan kedua dan ketiga siswa hanya mengingat informasi yang sudah dipelajari pada pertemuan sebelumnya. Aktivitas siswa dalam mendengarkan penjelasan guru tertinggi pada pertemuan pertama sebab siswa dominan mendengarkan penjelasan guru pada materi baru. Aktivitas siswa dalam menyampaikan pendapat kepada kelas tertinggi pada pertemuan ketiga. Selain itu aktivitas siswa dalam melakukan pengamatan, merencanakan eksperimen, melakukan eksperimen, atau bekerja frekuensinya lebih besar pada pertemuan kedua dan pertemuan ketiga terbesar dibandingkan aktivitas lain. Aktivitas ini terlihat paling tinggi persentasenya karena siswa terlihat semakin tertarik belajar menggunakan laboratorium virtual yang terlihat dari persentase yang paling banyak di antara semua aktivitas.

Hasil pengamatan aktivitas siswa pada pembelajaran menggunakan laboratorium real dan laboratorium virtual rata-rata mengalami peningkatan aktivitas dalam menyelesaikan permasalahan dengan pendekatan keterampilan proses dan model pembelajaran inkuiri. Hal ini sesuai dengan pendapat Sanjaya (2008) yang mengatakan bahwa: 1) model inkuiri menekankan pada aktivitas siswa secara maksimal untuk mencari dan menemukan, artinya strategi inkuiri menempatkan siswa sebagai subyek belajar, 2) seluruh aktivitas yang dilakukan siswa diarahkan siswa diarahkan untuk mencari dan menemukan jawaban sendiri dari suatu pertanyaan, sehingga diharapkan dapat menumbuhkan sikap percaya diri (self believe) karena pembelajaran inkuiri mampu melibatkan siswa dalam proses belajar. Keterlibatan dalam hal ini bukan hanya keterlibatan mental intelektual atau berpikir saja namun juga keterlibatan sosial dan emosional, siswa akan terbiasa bekerja secara logis dan sistematik dan mengembangkan sikap percaya diri siswa. Pendapat tersebut senada dengan hasil penelitian Andriani (2011) yang menyimpulkan bahwa penerapan model pembelajaran inkuiri terbimbing dapat meningkatkan antusias siswa dalam pelaksanaan kegiatan pembelajaran dan siswa menjadi fokus dalam pelaksanaan pembelajaran.

\section{Pencapaian Keterampilan Proses dan Hasil Belajar Produk}

Data nilai keterampilan proses dan hasil belajar produk menggunakan laboratorium real dan laboratorium virtual yang dipaparkan pada Tabel 5 dan Tabel 6:

\begin{tabular}{|c|c|c|c|c|}
\multicolumn{5}{|c}{ Tabel 5. Data Nilai Keterampilan Proses Siswa } \\
\hline No. & $\begin{array}{c}\text { Lab } \\
\text { Raal }\end{array}$ & $\begin{array}{c}\text { Lab } \\
\text { Virtual 1 }\end{array}$ & $\begin{array}{c}\text { Lab } \\
\text { Virtual 2 }\end{array}$ & $\begin{array}{c}\text { Lab } \\
\text { Virtual 3 }\end{array}$ \\
\hline 1 & 85 & 90 & 85 & 85 \\
\hline 2 & 85 & 95 & 60 & 85 \\
\hline 3 & 85 & 85 & 70 & 75 \\
\hline 4 & 60 & 65 & 71 & 70 \\
\hline 5 & 95 & 70 & 80 & 80 \\
\hline 6 & 75 & 95 & 85 & 85 \\
\hline 7 & 81 & 85 & 85 & 65 \\
\hline 8 & 80 & 91 & 60 & 95 \\
\hline 9 & 85 & 83 & 90 & 81 \\
\hline 10 & 85 & 75 & 85 & 85 \\
\hline 11 & 60 & 75 & 80 & 65 \\
\hline 12 & 70 & 80 & 83 & 70 \\
\hline 13 & 71 & 90 & 95 & 95 \\
\hline 14 & 65 & 90 & 85 & 85 \\
\hline 15 & 85 & 85 & 91 & 91 \\
\hline 16 & 90 & 81 & 83 & 83 \\
\hline 17 & 75 & 71 & 70 & 75 \\
\hline 18 & 65 & 85 & 65 & 80 \\
\hline 19 & 85 & 70 & 80 & 85 \\
\hline 20 & 80 & 85 & 90 & 81 \\
\hline 21 & 75 & 75 & 65 & 71 \\
\hline 22 & 75 & 70 & 81 & 75 \\
\hline 23 & 80 & 65 & 100 & 70 \\
\hline 24 & 60 & 80 & 85 & 80 \\
\hline
\end{tabular}




\begin{tabular}{|c|c|c|c|c|}
\hline 25 & 85 & 75 & 75 & 90 \\
\hline 26 & 63 & 75 & 75 & 100 \\
\hline 27 & 90 & 85 & 80 & 95 \\
\hline 28 & 85 & 75 & 90 & 80 \\
\hline 29 & 75 & 80 & 100 & 85 \\
\hline 30 & 80 & 90 & 75 & 90 \\
\hline 31 & 60 & 81 & 85 & 85 \\
\hline 32 & 75 & 80 & 75 & 81 \\
\hline 33 & 76 & 60 & 60 & 71 \\
\hline 34 & 81 & 80 & 75 & 75 \\
\hline 35 & 75 & 70 & 75 & 75 \\
\hline 36 & 80 & 90 & 85 & 90 \\
\hline 37 & 100 & 95 & 81 & 75 \\
\hline 38 & 80 & 75 & 75 & 80 \\
\hline 39 & 100 & 80 & 80 & 75 \\
\hline 40 & 75 & - & 85 & - \\
\hline $\begin{array}{c}\text { rata- } \\
\text { rata }\end{array}$ & 79.12 & 80.18 & 79.88 & 81.16 \\
\hline
\end{tabular}

\begin{tabular}{|c|c|c|c|c|}
\hline 27 & 90 & 85 & 80 & 95 \\
\hline 28 & 85 & 75 & 90 & 80 \\
\hline 29 & 75 & 80 & 100 & 85 \\
\hline 30 & 80 & 90 & 75 & 90 \\
\hline 31 & 65 & 80 & 85 & 85 \\
\hline 32 & 75 & 70 & 75 & 80 \\
\hline 33 & 75 & 60 & 60 & 70 \\
\hline 34 & 80 & 80 & 75 & 75 \\
\hline 35 & 75 & 70 & 75 & 75 \\
\hline 36 & 80 & 90 & 85 & 90 \\
\hline 37 & 100 & 95 & 80 & 75 \\
\hline 38 & 80 & 75 & 75 & 80 \\
\hline 39 & 100 & 80 & 80 & 60 \\
\hline 40 & 75 & - & 85 & - \\
\hline $\begin{array}{c}\text { rata- } \\
\text { rata }\end{array}$ & 78.25 & 79.48 & 79.63 & 80.26
\end{tabular}

Berdasarkan data nilai keterampilan proses dan hasil belajar produk, dilakukan uji hipotesis untuk mengetahui adanya perbedaan pencapaian keterampilan proses pada setiap kelas menggunakan SPSS 16 dan hasilnya didapatkan bahwa taraf signifikan semua hubungan antar kelas bernilai di atas 0,05 sehingga dapat disimpulkan tidak terdapat perbedaan pada masing-masing kelas terhadap kelas lain artinya tidak terdapat perbedaan nilai keterampilan proses dan hasil belajar produk pada pembelajaran yang menggunakan laboratoriun real dan laboratorium virtual serta pada semua kelas replikasi.

\section{Respon Siswa}

Berdasarkan hasil respon siswa menunjukkan bahwa sebesar $89 \%$ siswa merasa tertarik terhadap komponen materi ajar, LKS, suasana belajar dan pembelajaran dengan percobaan pada laboratorium real. Respon siswa terhadap keterbaruan komponen menunjukkan bahwa $75 \%$ siswa merasa baru. Respon siswa terhadap bahasa dalam buku, materi/isi buku, contoh-contoh soal, LKS dan petunjuk praktikumnya adalah $77 \%$ merasa mudah memahaminya. Respon siswa terhadap penjelasan guru pada saat KBM berlangsung dan bimbingan guru dalam menemukan konsep melalui eksperimen adalah 64\%. Respon siswa terhadap cara mengajar guru adalah $70 \%$ baik mulai dari teknik merumuskan masalah, merumuskan hipotesis, mengidentifikasi variabel, merancang dan melakukan eksperimen, mengambil dan menganalisis data serta menarik kesimpulan sehingga merasa jelas sehingga banyak siswa merespon bahwa komponen keterampilan proses mudah untuk diikuti selama kegiatan pembelajaran berlangsung. Siswa merespon bahwa butir soal sebesar $62 \%$ yang diujikan termasuk mudah, sedangkan $38 \%$ siswa yang lain menyatakan bahwa butir soal termasuk 
sulit.

Respon siswa terhadap penggunaan laboratorium virtual menunjukkan bahwa $90 \%$ siswa merasa tertarik terhadap komponen materi ajar, LKS, suasana belajar dan pembelajaran karena siswa merasa senang belajar dengan media Acid Base Titration Lab pada laboratorium virtual. Persentase respon siswa terhadap penggunaan laboratorium virtual dalam 3 kali eksperimen menunjukkan hasil yang tidak berbeda secara signifikan sehingga penggunaan laboratorium virtual dengan beberapa mengulangan memberikan hasil yang reliabel.

\section{SIMPULAN}

Berdasarkan hasil penelitian dan pembahasan dapat disimpulkan bahwa tidak terdapat perbedaan yang signifikan pada keterampilan proses dan hasil belajar siswa dengan menggunakan laboratorium real dan laboratorium virtual materi titrasi asam basa artinya laboratorium virtual dapat digunakan sebagai media simulasi bagi sekolah yang memiliki laboratorium real yang memadai sebelum siswa menghadapi peralatan laboratorium real dan dapat digunakan sebagai pembelajaran alternatif bagi sekolah yang memiliki keterbatasan dalam hal kegiatan laboratoriumnya. Laboratorium virtual bukanlah kompetitor dan tidak difungsikan untuk menggantikan laboratorium real melainkan merupakan perluasan dari laboratorium real, oleh karena itu laboratorium virtual dapat digunakan untuk melengkapi keterbatasan dari laboratorium real.

\section{DAFTAR PUSTAKA}

Arikunto, Suharsimi. 2002. Prosedur Penelitian Suatu Pendekatan Praktek. Jakarta : Rineka Cipta.

Bailenson, Jeremy. 2008. "The Use of Immersive Virtual Reality in the Learning Sciences: Digital Transformations of Teachers, Students, and Social Context". The Journal of The Learning Sciences. Vol 17 , p. 102-141.

Carin, Arthur A. 1993. Teaching Modern Science. Sixth Edition. New York: Merrill, an imprint of Macmillan Publishing Cmaompany.

Conny Semiawan. 1992. Pendekatan Keterampilan Proses. Jakarta: Gramedia Widisarana Indonesia.

Dimyati. 2002. Belajar dan Pembelajaran. Jakarta : Rineka Cipta.

Dineva, Snejana and Stokova, Vania. 2011. Application of Interactive Devices and Virtual lab in Chemistry Learning. The 6th International Conference on Virtual Learning ICVL 2011. p. 262-267.

Georgiou, J., Dimitropoulos, K., and Manitsaris A. 2007. A Virtual Reality Laboratory for Distance Education in Chemistry. International Journal of Social and Human
Sciences. Vol 1, p. 306-313.

Hamalik, Oemar. 2003. Proses Belajar Mengajar. Jakarta: Bumi Aksara.

Insani, Dewi. 2011. Pengembangan Perangkat Pembelajaran Listrik Dinamis Berbasis Inkuiri Untuk Melatihkan Keterampilan Berpikir Siswa SMAN 1 Tuban. Tesis Magister Pendidikan tidak dipublikasikan: Pascasarjana Unesa.

Ibrahim, Muslimin. 2005. Assesmen Berkelanjutan. Surabaya : University Press.

Lutfi, Achmad. 2013. "Uji Coba Pembelajaran IPA dengan LKS sebagai Penunjang Media Virtual Phet untuk Melatih Keterampilan Proses pada Materi Hukum Archimedes”. Jurnal Pendidikan makSains ePensa. Vol. 01 No. 02, hal. 15-20.

Mosterman, P. J., Dorlandt, M. A., Campbell, J, O. 1994. "Virtual Engineering Laboratories: Design and Experiments". Journal of Engineering

Nur, M. 2004. Teori-Teori Perkembangan. Surabaya : PSMS UNESA.

Nur, M dan Wikandari, P.R. 2000. Pengajaran Berpusat Kepada Siswa dan Pendekatan Kontruktivis Dalam Pengajaran. Surabaya: Pusat Studi Matematika dan IPA Sekolah Universitas Negeri Surabaya.

Nur, M. 2011. Modul Keterampilan-Keterampilan Proses Sains. Surabaya : PSMS UNESA.

Ratumanan, T.G. 2006 Evaluasi Hasil Belajar yang Relevan dengan Kurikulum Berbasis Kompetensi. Surabaya: Unesa University Press

Ratumanan, T.G., Laurens, T. 2011. Penilaian Hasil Belajar pada Tingkat Satuan Pendidikan. 2011. Surabaya: Unesa University Press.

Sanjaya, Wina. 2008. Strategi Pembelajaran Berorientasi Standar Proses Pendidikan. Jakarta : Kencana Prenada Media Group.

Subagyo, Y. Wiyanto, P. Marwoto. 2009. "Pembelajaran dengan Pendekatan Keterampilan Proses Sains untuk Meningkatkan Penguasaan Konsep Suhu dan Pemuaian". Jurnal Pendidikan Fisika Indonesia . Vol 5, hal. 42-46.

Sudjana, Nana. 2010. Penilaian Hasil Proses Belajar Mengajar. Bandung : PT Remaja Rosdakarya. Sujana. 1996. Metoda Statistika. Bandung: Tarsito.

Suyidno. 2010. Pengembangan Perangkat Pembelajaran Inovatif untuk Melatihkan Keterampilan Memecahkan Masalah kepada Siswa Sekolah Menengah Pertama. Tesis Magister Pendidikan tidak dipublikasikan: Pascasarjana Unesa.

Tuysuz, Cengiz. 2010. "The Effect of the Virtual Laboratory on Students' Achievement and Attitude in Chemistry". International Online Journal of Educational Sciences. Vol. 2 (1), p.37-53. 